\title{
PENGARUH FIRM SIZE DAN FINANCIAL LEVERAGE TERHADAP FINANCIAL PERFORMANCE PADA PT. JAPFA COMFEED INDONESIA
}

\author{
Sumarno \\ Magister Ekonomi Syariah, UIN Sunan Gunung Djati Bandung \\ sumarnomksf@gmail.com \\ Ade Ponirah \\ Magister Ekonomi Syariah, UIN Sunan Gunung Djati Bandung \\ adeponirah@gmail.com \\ Nurudin Falah \\ Magister Ekonomi Syariah, UIN Sunan Gunung Djati Bandung \\ Falahnurudin@gmail.com
}

\section{Abstract}

The company's financial performance is the first benchmark to build investor confidence. Describes the state of the company and can be a reference for investment decisions. This article aims to increase the influence of firm size and financial leverage on financial performance of PT.Japfa Comfeed Indonesia firm size shows the size of a company. While financial leverage the proportion of debt usage to finance its investment. This article also uses descriptive methods and quantitative approaches, namely to describe the results of research whose data is presented in numerical form. The data in this article is secondary data taken from financial statements PT. Japfa Comfeed Indonesia, Tbk. and supported by literature and documentation studies, which are processed statistically and quantitatively. The results of this study concluded that partially firm size has an insignificant influence on financial performance. But for financial leverage has a significant influence on financial performance. Simultaneously, firm size and financial leverage have a significant influence on financial performance with a contribution of $66.8 \%$ meaning that $33.2 \%$ of financial performance is influenced by other factors that are not examined in this study.

\section{Keywords: Firm Size, Financial Leverage, Financial Performance}

\begin{abstract}
Abstrak
Kinerja keuangan perusahan merupakan tolak ukur pertama untuk membangun kepercayaan investor. Menggambarkan keadaan perusahaan dan dapat menjadi acuan keputusan investasi.. Artikel ini bertujuan untuk menguji pengaruh firm size dan financial leverage terhadap financial performance PT. Japfa Comfeed Indonesia, Tbk. firm size menunjukkan besar kecilnya suatu perusahaan. Sedangkan financial leverage proporsi penggunaan utang untuk membiayai investasinya. Artikel ini juga menggunakan metode deskriprif dan pendekatan kuantitatif, yakni untuk mendeskripsikan hasil penelitian yang datanya disajikan dalam bentuk numerik. Data pada artikel ini merupakan data sekunder yang diambil dari laporan keuangan PT. Japfa Comfeed Indonesia, Tbk dan didukung dengan studi kepustakaan dan dokumentasi, yang diolah secara statistik dan kuantitatif. Hasil penelitian ini menyimpulakan bahwa secara parsial firm size memiliki pengaruh tidak signifikan terhadap financial performance. Namun untuk financial leverage memiliki pengaruh signifikan terhadap financial performance. Secara simultan firm size dan financial leverage memiliki pengaruh signifikan terhadap financial performance dengan kontribusi sebesar 66,8\% artinya 33,2\% financial performance dipengaruhi oleh faktor-faktor lain yang tidak di teliti dalam penelitian ini.
\end{abstract}

Kata Kunci: Firm Size, Financial Leverage, Financial Performance 


\section{Pendahuluan}

Investasi merupakan langkah awal kegiatan produksi dan menjadi faktor untuk meningkatkan pertumbuhan ekonomi. Serta menjadi langkah awal dalam kegiatan pembangunan ekonomi. Terjadinya dinamika dalam penanaman modal, mempengaruhi tinggi rendahnya pertumbuhan ekonomi dan mencerminkan tinggi dan lesunya pembangunan (Sari \& Syechalad, 2016). Saat ini banyak negara-negara yang membuat kebijakan untuk meningkatkan investasi baik itu domestik maupun modal asing. Hal ini bertujuan agar kegiatan investasi menjadi pemicu pendorong kegiatan ekonomi suatu Negara, penyerapan tenaga kerja, peningkatan output yang dihasilkan, penghematan devisa atau bahkan penambahan devisa (Kurniawan, 2016).

Untuk kelancaran proses ini tentunya membutuhkan tempat atau wadah yang membantu mempertemukan investor dengan emiten yaitu pasar modal. Pasar modal merupakan suatu tempat bertemunya para penjual dan pembeli untuk melakukan transaksi dalam rangka memperoleh modal (Kasmir, 2008). Pasar modal kini menjadi ikon ekonomi modern. Kegiatan industri ini sering menjadi simbol dan gambaran ekonomi masyarakat serta menjadi pilar perekonomian negara-negara maju (Fakhruddin, 2008). Kini pasar modal sudah menjadi indikator ekonomi makro suatu negara. Naik turunnya indeks suatu bursa dapat dibaca sebagai cermin dinamika ekonomi negara tersebut (Widioatmodjo, 2015).

Dalam pasar modal terdapat berbagai instrument keuangan jangka panjang yaitu dalam bentuk utang maupun modal. Berbagai instrumen ini membantu perusahaan mencari dana dengan cara menjual hak kepemilikan kepada masyarakat. Dengan begitu perusahaan mampu bertahan dan bersaing untuk jangka waktu yang panjang. Salah satu cara perusahaan untuk dapat bersaing dan bertahan yaitu dengan meningkatkan financial performance. Penelitian ini menggunakan rasio Return On Assets (ROA) untuk merepresentasikan financial performace. Pada penelitian ini, peneliti akan menganalisis faktor apa yang mempengaruhi financial performance PT. Japfa Comfeed Indonesia Tbk. yang bergerak di industri makanan terbesar di Indonesia. Peneliti mengasumsikan firm size dan financial leverage akan mempengaruhi tinggi rendahnya financial performance.

Menurut Brigham dan Houston Firm Size merupakan ukuran besar kecilnya sebuah perusahaan yang ditunjukkan atau dinilai oleh total asset, total penjualan, jumlah laba, beban pajak dan lain-lain (Brighman \& Houston, 2010). Pada umumnya perusahaan besar memiliki total aktiva yang besar pula sehingga dapat menarik investor untuk menanamkan modalnya pada perusahaan tersebut dan akhirnya saham tersebut mampu bertahan pada harga yang tinggi (Viandita et al., 2013). Salah satu tolak ukur yang menunjukkan besar kecilnya perusahaan adalah ukuran aktiva dari perusahaan. Semakin besar total aktiva maka semakin mampu perusahaan untuk menghasilkan laba. Semakin besar persahaan menghasilkan laba, maka akan besar membagikan dividen. Selain itu, jika kemampuan perusahaan untuk menghasilkan laba meningkat maka harga saham akan meningkat sehingga investor akan tertarik untuk berinvestasi (Adiwiratama, 2012).

Financial leverage menunjukkan proporsi atas penggunaan utang untuk membiayai investasinya (Sartono, 2010). Pada penelitian ini financial leverage direpresentasikan oleh rasio Debt to Equity Ratio (DER). Semakin tinggi financial leverage dalam laporan keuangan maka akan semakin besar risiko yang dihadapi oleh investor. Penggunaan hutang yang tinggi akan mempengaruhi terhadap keberlangsungan perusahaan serta akan menjadi beban yang berat dalam melaksanakan operasionalnya (Azzahra \& Nasib, 2019). Perusahaan dengan tingkat 
hutang yang rendah memiliki risiko yang lebih kecil jika kondisi ekonomi sedang menurun, tetapi jika keadaan membaik akan memberikan hasil yang lebih rendah. Begitupun sebaliknya perusahaan yang memiliki tingkat hutang yang tinggi memiliki risiko yang cukup besar tetapi juga memiliki kesempatan untuk mendapatkan laba yang tinggi (Weston \& Copeland, 1995). Namun pada penelitian ini penulis mengasumsikan jika financial leverage perusahaan cukup tinggi maka akan sangat beresiko dalam operasional perusahaan.

Berdasarkan teori yang telah di paparkan, maka dapat dirumuskan jika Firm Size dan Financial Leverage berpengaruh terhadap Financial Performance. Penelitian ini di lakukan pada salah satu perusahaan yang terdaftar di Indeks Saham Syariah Indonesia (ISSI) yaitu PT. Japfa Comfeeed Indonesia, Tbk yang bergerak di bidang agri-food terbesar dan terkemuka di tanah air. Perusahaan ini penghasil protein hewani yang berkualitas dan terpercaya, melayani kebutuhan masysrakat Indonesia sejak tahun 1975. Berikut data Firm Size, Financial Leverage dan Financial Performance pada PT. Japfa Comfeed Indonesia, Tbk periode 2010-2019

\section{Tabel 1 Data Penelitian}

\begin{tabular}{|c|c|c|c|}
\hline \multirow{2}{*}{ Peridoe } & Firm Size & Leverage & Financial Perfoemance \\
& & & 13,7 \\
\hline 2010 & 18,06 & 1,1 & 7,5 \\
\hline 2011 & 15,93 & 1,4 & 9,0 \\
\hline 2012 & 16,21 & 1,4 & 4,0 \\
\hline 2013 & 16,52 & 2,0 & 2,1 \\
\hline 2014 & 16,57 & 2,1 & 3,1 \\
\hline 2015 & 16,66 & 1,8 & 11,3 \\
\hline 2016 & 16,77 & 1,1 & 6,7 \\
\hline 2017 & 14,31 & 1,3 & 9,7 \\
\hline 2018 & 16,95 & 1,3 & 7,4 \\
\hline 2019 & 17,04 & 0,8 & Tata dalam Persen (\%) \\
\hline \multicolumn{4}{|c|}{ Sumber: Laporan Tahunan PT. Japfa Comfeed Indonesia, Tbk } \\
\hline \multicolumn{4}{|c|}{} \\
\hline
\end{tabular}

Dari tabel di atas terdapat data yang fluktuatif setiap tahun nya, pada tahun 2011 firm size mengalami penurunan dengan di ikuti oleh financial performance namun financial leverage meningkat. Selanjutnya dua tahun berturut-turun pada tahun 2013 hinga 2014 kedua variabel independen meningkat namun financial performance sebagai variabel dependen menurun. Menginjak tahun 2015 hingga 2016 hanya financial leverage saja yang menurun. Sebaliknya pada tahun 2017 hanya financial leverage saja yang meningkat. Di tutup dengan tahun 2019 firm size meningkat namun financial leverage dan finanicial performance menurun. Berdasarkan data di atas maka dipandang perlu melakukan penelitian terhadap PT. Japfa Comfeed Indonesia Tbk.

\section{Metode}

Penelitian ini diolah menggunkaan metode deksripstif dengan pendekatan kuantitaif yang menguraikan secara sistematis semua fakta serta hubungan antar variabel dengan menganalisis data berupa angka menggunakan uji statistik. Data yang digunakan dalam penelitian ini menggunakan data sekunder yang berupa laporan keuangan tahunan PT. Japfa Comfeed Indonesia, Tbk. dari website www.idx.co.id dengan jumlah sampel 10 periode mulai dari tahun 
2010-2019. Teknik analisis data diolah secara statistik dan kuantitatif menggunakan bantuan perangkat lunak SPSS. Teknik penghitungan yang digunakan adalah analisis regresi, uji hipotesis, dan uji kekuatan hubungan dengan R Square dan pearson producr moment.

\section{Hasil dan Pembahasan}

Artikel ini akan menganalisis pengaruh firm size dan financial leverage terhadap financial performance PT. Japfa Comfeed Indonesia Tbk. periode 2010-2019 secara parsial dan simultan.

\subsection{Pengaruh Firm Size terhadap Financial Performance pada PT. Japfa Comfeed Indonesia,Tbk Peridoe 2010-2019}

Firm Size suatu konteks yang mengukur tuntutan pelayanan atau produk organisasi (Torang J.E, 2012) Firm Size menunjukkan nilai besar kecilnya perusahaan (Annisa, 2008). Firm Size terbagi menjadi tiga kategori yaitu perusahaan besar (large firm), perusahaan menengah (medium size), dan perusahaan kecil (small firm). Karena firm siže suatu skala yang dapat diklasifikasikan besar kecil perusahaan menurut berbagai cara, antara lain: total aktiva, log size, nilai pasar saham, dan lain-lain (Isbanah, 2015). Cerminan kemampuan perusahaan yaitu mempunyai total asset yang besar. Biaya pengumpulan dan pemrosesan informasi dapat berkurang jika ukuran perusahaan berskala besar. Sudarmadji dan Sularto dalam penelitiannya menyatakan perusahaan yang berskala besar mempunyai sumber daya yang besar pula, maka dampaknya mampu membiayai penyediaan informasi untuk keperluan internal dan eksternal seperti investor dan kreditor, sehingga untuk pengungkapan lebih luas tidak memerlukan tambahan biaya yang besar. Perusahaan yang berskala besar dan mapan akan lebih mudah untuk menuju ke pasar modal dan tingkat kepercayaan investor juga akan lebih besar, karena mempunyai fleksibilitas penempatan investasi yang lebih baik (Sudarmadji \& Sularto, 2007).

Namun penelitian ini tidak sesuai dengan teori yang telah dipaparkan di atas, berikut hasil penelitian yang telah di lakukan:

Tabel 1 Hasil Regresi Linear dan Uji t Pengaruh Firm Size terhadap

Financial Performance

Coefficients $^{\mathrm{a}}$

\begin{tabular}{|c|c|c|c|c|c|c|}
\hline & \multirow[b]{2}{*}{ Model } & \multicolumn{2}{|c|}{ Unstandardized Coefficients } & $\begin{array}{l}\text { Standardized } \\
\text { Coefficients }\end{array}$ & \multirow[b]{2}{*}{$\mathrm{t}$} & \multirow[b]{2}{*}{ Sig. } \\
\hline & & $\mathrm{B}$ & Std. Error & Beta & & \\
\hline \multirow[t]{2}{*}{1} & (Constant) & -16.191 & 20.809 & & -.778 & .459 \\
\hline & FirmSize & 1.433 & 1.259 & .373 & 1.138 & .288 \\
\hline
\end{tabular}

a. Dependent Variabel: Financial Performance

Sumber: Hasil output SPSS versi 20

Persamaan yang didapatkan dari hasil SPSS di atas adalah:

Financial Performance $=-16,191+1,433$ Firm Size

Berdasarkan pada persamaan regresi tersebut, dapat dijelaskan apabila nilai $\mathrm{X}_{1}$ (firm size) bernilai nol, maka Y (financial performance) bernilai -16,191. Sementara itu, jika $\mathrm{X}_{1}$ (firm size) berubah sebesar 1 (satu) satuan, maka akan memberikan dampak pada peningkatan terhadap Y (financial performance) sebesar 1,433. Selanjutnya, persamaan regresi linear sederhana tersebut 
memperlihatkan bahwa firm size memiliki arah pengaruh yang positif terhadap financial performance.

Pengaruh firm size terhadap financial performance dapat dilihat dari hasil uji $t$ dimana hasil di atas tidak memenuhi kriteria berpengaruh karena 1,138<2,306 dengan Sig. 0,288 > 0,05. Sehingga peneliti mendapatkan hasil akhir bahwa firm size tidak memiliki pengaruh terhadap financial performance PT. Japfa Comfeed Indonesia, Tbk. periode 2010-2019.

Selanjutnya kekuatan hubungan dan kontribusi pengaruh firm size terhadap financial performance dapat dilihat pada tabel berikut:

\section{Tabel 2 Hasil Uji Korelasi dan Koefisien Determinasi}

\begin{tabular}{|c|c|c|c|c|}
\hline \multicolumn{1}{|c|}{ Model Summary } \\
Model & $\mathrm{R}$ & R Square & Adjusted R Square & $\begin{array}{c}\text { Std. Error of the } \\
\text { Estimate }\end{array}$ \\
\hline 1 & $.373^{\mathrm{a}}$ & .139 & .032 & 3.61351 \\
\hline
\end{tabular}

a. Preictors: (Constant), firm size

Sumber: hasil output SPSS versi 20

Berdasarkan perhitungan SPSS di atas dapat diketahui besarnya hubungan firm size terhadap financial performance adalah 0,373 korelasi tersebut termasuk kategori lemah. Dan R Square $\left(\mathrm{r}^{2}\right)$ 0,139 atau sama dengan 13,9\%. Artinya, financial performance hanya 13,9\% dipengaruhi oleh firm size, sedangkan sisanya 86,1\% financial performance dipengaruhi oleh faktor lain.

Hasil output SPSS di atas menunjukkan hasil yang berbeda dengan teori dari Adiwiratama. Menurut peneliti semakin besar firm size maka akan berakibat semakin rendah financial performance. Hal ini di sebabkan dari faktor internal yaitu belum didukung pengelolaan perusahaan yang baik.. Firm size tidak dapat digunakan sebagai acuan bahwa perusahaan yang besar memiliki kinerja yang bagus. Pada perusahaan yang bergerak di bidang agri-food banyak kendala yang di hadapi, besarnya total asset tidak menjamin kinerja perusahaan baik karena ada faktor produksi yang terhambat salah satunya adanya larangan impor jagung yang menjadi bahan baku pakan ternak mulai di berlakukan pada tahun 2017.

Semenajak di berlakukannya aturan tersebut beban produksi perusahaan naik, sebab kontribusi pakan ternak dalam produksi peternakan unggas mencapai 70\%. Walapun jumlah pendapatan setiap tahunnya meningkat namun laba perusahaan ini turun akibat beban penjualan yang terus bertambah. Sehingga tingginya total asset yang dimiliki tidak dapat dimaksimalkan oleh perusahaan dalam penjualan yang berdampak pada pencapaian laba (Wufron, 2017). Pada tahun 2018 perusahaan ini terus berusaha mengembangkan terutama produk akhir yaitu produk ayam potong siap masak serta produk siap saji. Hal ini dilakukan untuk berjaga-jaga dalam menghadapi banyak tantangan di tahun berikutnya.

Tingginya total asset yang dimiliki bisa saja menjadi beban jika tidak digunakan dengan maksimal oleh perusahaan sedangkan biaya yang dikeluarkan untuk asset yang dimiliki harus tetap dipenuhi. Terutama asset tetap yang dimiliki perusahaan memerlukan pengeluaran yang bertujuan agar tetap memenuhi kebutuhan perusahaan seperti pemeliharaan, penggantian, perbaikan (improvement), penambahan (addition) dan penusunan kembali (rearrangement) akibat penyusunan kembali route produksi (Wufron, 2017). 


\subsection{Pengaruh Financial Leverage terhadap Financial Performance Pada PT. Japfa Comfeed Indonesia, Tbk Periode 2010-2019}

Dalam kegiatan operasional perusahaan tentunya membutuhkan dana untuk memenuhi semua kebutuhan demi keberlangsungan hidup perusahaan. Keputusan dalam memenuhi sumber dana ini akan berdampak pada financial performance. Sumber dana dapat di peroleh dari pihak internal ataupun eksternal. Keputusan ini akan di tentukan oleh pihak manajemen dengan mempertimbangkan baik buruknya dari masing-masing sumber dana tersebut. Salah satu sumber pendanaan yang sering diambil oleh manajemen yaitu dengan berhutang. Namun dalam keputusan ini akan menambah biaya berupa beban bunga yang harus dibayarkan (Ifada \& Inayah, 2017).

Financial leverage membuat perusahaan menggunakan sumber dana yang memberikan beban tetap. Tujuan penggunaan sumber dana ini untuk meningkatkan pengembalian kepada para pemegang saham biasa. Menurut Horne dan Wachowicz financial leverage akan menguntungkan (favorable) jika perusahaan mendapatkan pendapatan lebih besar dari beban tetap yang harus dibayar. Berapapun laba yang tersisa setelah beban tetap dibayar maka akan sepenuhnya menjadi milik para pemegang saham biasa. Financial leverage tidak menguntungkan (unfavorable) terjadi ketika perusahaan memiliki hasil pendapatan dari penggunaan dana lebih kecil dari pada beban tetap yang harus dibayar (Horne \& Wachowicz, 2007).

Hasil penelitian sesuai dengan teori yang dipaparkan diatas bahwa financial leverage memiliki pengaruh signifikan terhadap financial performance PT. Japfa Comfeed Indonesia Tbk. hasil penelitiannya sebagai berikut:

Tabel 3 Hasil Uji Regresi Linear dan Uji $t$ Pengaruh Financial Leverage terhadap Financial Performance

Coefficients $^{a}$

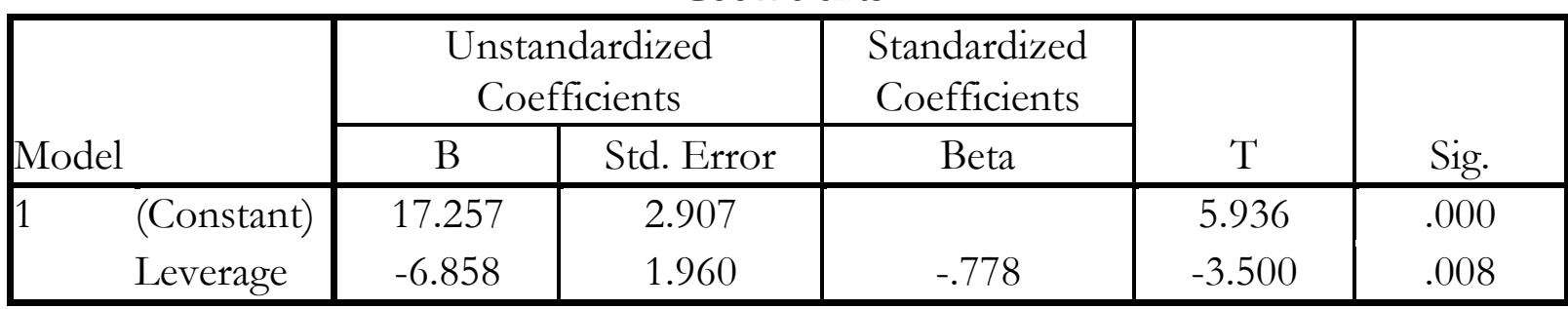

a. Dependent Variabel: Financial Performance

Sumber: hasil output SPSS versi 20

Berdasarkan tabel di atas diperoleh persamaan:

$$
\text { Financial Performance }=17,257-6,858
$$

Berdasarkan pada persamaan regresi tersebut, bisa dijelaskan apabila nilai $\mathrm{X}_{2}$ (financial leverage) bernilai nol, maka Y (financial performance) bernilai 17,257. Sementara itu, jika $\mathrm{X}_{2}$ (financial leverage) berubah sebesar 1 (satu) satuan, maka akan memberikan dampak pada penurunan terhadap Y (financial performance) sebesar 6,858. Selanjutnya, persaman regresi linear sederhana tersebut memperlihatkan bahwa financial leverage memberikan arah negatif terhadap financial performance.

Pengaruh financial leverage terhadap financial performance dapat dilihat dari hasil uji $t$ dimana hasil di atas memenuhi kriteria berpengaruh karena 3,500 > 2,306 dengan Sig. 0,008 $<0,05$. 
Sehingga peneliti mendapatkan hasil akhir bahwa financial leverage memiliki pengaruh terhadap financial performance PT. Japfa Comfeed Indonesia, Tbk. periode 2010-2019.

Selanjutnya kekuatan hubungan dan kontribusi pengaruh financial leverage terhadap financial performance dapat dilihat pada tabel berikut:

Tabel 4 Hasil Uji Korelasi dan Koefisien Determinasi

Model Summary

\begin{tabular}{|c|c|c|c|c|}
\hline Model & $\mathrm{R}$ & R Square & Adjusted R Square & $\begin{array}{c}\text { Std. Error of the } \\
\text { Estimate }\end{array}$ \\
\hline 1 & $.778^{\mathrm{a}}$ & .605 & .556 & 2.44828 \\
\hline
\end{tabular}

a. Predictors: (Constant), financial leverage

Sumber: hasil outout SPSS versi 20

Berdasarkan perhitungan SPSS di atas dapat diketahui besarnya hubungan financial leverage terhadap financial performance adalah 0,778 dimana berada pada kriteria kuat. Dan $\mathrm{R}$ Square $\left(\mathrm{r}^{2}\right)$ menunjukkan nilai koefisien determiansi, besarnya $\mathrm{r}^{\mathrm{r}}$ adalah 0,605 atau sama dengan $60,5 \%$. Hal ini berarti financial leverage mampu mempengaruhi besar kecilnya financial performance sebesar $60,5 \%$ kemudian sisanya sebesar 39,5\% dipengaruhi oleh faktor lain.

Dari hasil analisis di atas financial leverage memiliki pengaruh terhadap financial performance. Hasil penelitian ini sejalan dengan teori yang di uangkapkan oleh Horne dan Wachowicz financial leverage akan tidak menguntungkan (unfavorable) terjadi ketika perusahaan memiliki hasil pendapatan dari penggunaan dana lebih kecil dari pada beban tetap yang harus dibayar. Semkain rendah rasio hutang maka akan semakin bagus perusahaan itu. Artinya sebagian kecil asset perusahaan yang dibiayai dengan hutang. Semakin besar rasio ini maka semakin besar juga leverage perusahaan (Sartono, 2010). Faktor lain yang dapat mempengaruhi keberhasilan perusahaan dalam mengelola sumber dana hutang yaitu keadaan perekonomian Negara. Jika keadaan perekonomian tidak stbail maka akan berdampak pada operrasional perusahaan.

\subsection{Pengaruh Firm Size dan Financial Leverage terhadap Financial Performance pada PT. Japfa Comfeed Indonesia,Tbk Periode 2010-2019}

Financial performance merupakan suatu analisis yang dilakukan untuk melihat sejauh mana suatu perusahaan telah melaksanakan dengan menggunakan aturan-aturan pelaksanaan keuangan secara baik dan benar. Seperti membuat laporan keuangan yang telah memenuhi standard ketentuan dalam SAK (Standar Akuntansi Keuangan) (Fahmi, 2012). Bertujuan untuk mengukur prestasi yang dicapai oleh suatu organisasi dalam suatu periode tertentu mencerminkan tingkat keberhasilan pelaksanaan kegiatannya. Selain itu melihat kinerja organisasi secara keseluruhan, maka pengukuran kinerja juga dapat digunakan untuk menilai kontribusi suatu bagian dalam pencapaian tujuan keseluruhan maka financial performance dapat digunakan untuk menilai kontribusi suatu bagian dalam pencapaian tujuan secara keseluruhan (Efriyanti et al., 2012)

Firm size menunjukkan nilai besar kecilnya suatu perusahaan dapat dilihat dari seberapa besar total asset, nilai pasar sahan, dan lain-lain. Financial leverage menunjukkan penggunaan proporsi utang untuk membiayai investasinya. Berdasarkan pada teori yang telah di paparkan pada pembahasan di atas, penelitian ini antara firm size dan financial leverage memiliki pengaruh signifikan terhadap financial performance. Berikut hasilnya: 
Tabel 5 Hasil Uji F

ANOVAa

\begin{tabular}{|ll|c|c|c|c|c|}
\hline \multicolumn{1}{|c|}{ Model } & Sum of Squares & $\mathrm{df}$ & Mean Square & $\mathrm{F}$ & Sig. \\
\hline 1 & Regression & 81.110 & 2 & 40.555 & 7.052 & $.021^{\mathrm{b}}$ \\
Residual & 40.255 & 7 & 5.751 & & \\
Total & 121.365 & 9 & & & \\
\hline
\end{tabular}

a. Dependent Variabel: Financial Performance

b. Predictors: (Constant), Firm Size, Financial Leverage

Sumber: output hasil SPSS versi 20

Tabel di atas merupakan hasil uji hipotesis secara simultan, $\mathrm{F}$ hitung yang didapatkan adalah 7,052 dengan Sig. 0,021. Ini memenuhi kriteria berpengaruh, karena 7,052> 4,74 dan 0,021< 0,05. Sehingga, disimpulkan secara simultan variabel firm size dan financial leverage berpengaruh signifikan terhadap financial performance.

Selanjutnya kekuatan hubungan dan kontribusi pengaruh firm size dan financial leverage terhadap financial performance dapat dilihat pada tabel berikut:

\section{Tabel 4 Hasil Uji Korelasi dan Koefisien Determinasi}

Model Summary

\begin{tabular}{|c|c|c|c|c|}
\hline Model & $\mathrm{R}$ & $\mathrm{R}$ Square & Adjusted R Square & Std. Error of the Estimate \\
\hline 1 & $.818^{\mathrm{a}}$ & .668 & .574 & 2.39807 \\
\hline
\end{tabular}

a. Predictors: (Constant), Firm Size, Financial Leverage

Sumber: output hasil SPSS versi 20

Berdasarkan perhitungan SPSS di atas dapat diketahui besarnya hubungan firm size dan financial leverage terhadap financial performance adalah 0,818 berada pada interval $0,80-1,00$ yang berarti sangat kuat. Sedangkan, koefisien determinasi memiliki nilai 0,668 yang artinya terdapat hubungan antara firm size dan financial leverage terhadap financial performance sebesar 66,8\% sedangkan 33,2\% dipengaruhi oleh variabel lain yang tidak diteliti dalam penelitian ini.

Dalam penelitian ini hanya variabel $\mathrm{X}_{1}$ saja yang tidak signifikan, seperti yang telah di paparkan pada poin satu, besarnya nominal asset perusahaan belum tentu menggambarkan keadaan perusahaan baik, ada banyak faktor yang dapat mempengaruhinya. Keadaan perusahaan PT. Japfa Comfeed Indonesia, Tbk. mengalami kesulitan di tahun-tahun tertentu, terutama di tahun 2017 ketika di berlakukannya larangan impor jagung yang menjadi bahan pokok pakan ternak. Maka hal ini menyebabkan beban produksi dan beban penjualan meningkat, walapun pendapatan setiap tahunnya meningkat namun laba perusahaan ini terus menurun.

Berbeda dengan $\mathrm{X}_{2}$ didapat hasil uji $t$ yang signifikan, penggunaan sumber dana dari hutang tentunya memiliki banyak resiko, ada beban tetap yang harus di bayar di tambah dengan bunga. Jika perekekonomian sedang tidak baik maka hal ini akan berdampak buruk kepada kinerja keuangan perusahaan. Seperti yang telah di paparkan diatas adanya kebijakan larangan impor menjadi hambatan, perusahaan dituntut untuk memenuhi semua beban lebih mahal dari biasanya, maka jika rasio hutang semakin bertambah akan mencerminkan keadaan kinerja keuangan sedang tidak baik, hal ini akan melunturkan kepercayaan investor. 


\section{Kesimpulan}

Penelitian ini menghasilkan tiga kesimpulan akhir. Pertama, firm size tidak mampu mempengaruhi financial performance PT. Japfa Comfeed Indonesia, Tbk. periode 2010-2019. Kedua, financial leverage mampu mempengaruhi financial performance PT. Japfa Comfeed Indonesia, Tbk. periode 2010-2019 secara parsial. Dan terakhir, secara simultan firm size dan financial leverage berpengaruh signifikan terhadap financial performance PT. Japfa Comfeed Indonesia, Tbk. periode 2010-2019 dengan kontribusi sebesar 66,8\%. Implikasi dalam penelitian ini, PT. Japfa Comfeed Indonesia, Tbk untuk memperhatikan faktor-faktor produksi terutama bahan baku, karena jika harga bahan baku meningkat akan menambah beban produksi dan beban penjualan. Selain itu manajemen perusahaan harus lebih memaksimalkan dalam pengelolaan asset perusahaan, mengingat perusahaan sedang dalam kesulitan produksi walaupun jumlah pendapatan meningkat namun karena beban semakin membengkak maka laba yang di hasilkan menurun. Penggunaan sumber dana dari hutang juga harus di kelola dengan baik karena keadaan perusahaan dan perekonomian sedang tidak stabil maka pihak manajemen perusahaan harus mempertahankan kinerja keuangan dalam keadaan baik guna keberlangsungan hidup perusahaan serta menjaga kepercayaan investor pada perusahaan.

\section{Referensi}

Adiwiratama, J. (2012). Pengaruh Informasi Laba, Arus Kas Dan Size Perusahaan Terhadap Return Saham (Studi Empiris Pada Perusahaan Manufaktur Yang Terdaftar Di Bei). Jundan Adiwiratama, 2, 1-25.

Annisa, N. A. (2008). PENGARUH CORPORATE GOVERNANCE TERHADAP Nuralifmida Ayu Annisa Lulus Kumiasib Universitas Sebelas Maret. 123-136.

Azzahra, A. S., \& Nasib. (2019). Pengaruh Firm Size Dan Leverage Ratio Terhadap Kinerja Keuangan pada Perusahaan. Jwem Stie Mikroskil, 9(April), 13-20.

Brighman, F. E., \& Houston, J. (2010). Dasar - Dasar Manajemen Keuangan : Assetials Of Financial Management. Salemba Empat.

Efriyanti, F., Anggraini, R., \& Fiscal, Y. (2012). Analisis Kinerja Keuangan Sebagai Dasar Investor Dalam Menanamkan Modal Pada PT. Bukit Asam,TBK (Study Kasus pada PT. Bukit Asam,TBK). Jurnal Akuntansi Dan Keuangan, 3(2), 299-316. https://doi.org/10.36448/jak.v3i2.236

Fahmi, I. (2012). Analisis Kinerja Kenangan. Alfabeta.

Fakhruddin, H. M. (2008). Istilah Pasar Modal A-Z. PT Elex Media Komputindo.

Horne, V., \& Wachowicz. (2007). Fundamentals of Financial Management, Prinsip-Prinsip Manajemen Keuangan. Salemba Empat.

Ifada, L. M., \& Inayah, N. (2017). Analisis Pengaruh Tingkat Leverage Terhadap Kinerja Perusahaan (Studi pada Perusahaan Food and Beverage yang Terdaftar di BEI Tahun 2011-2013). Fokus Ekonomi, 12(1), 19-36. http://ejournal.stiepena.ac.id/index.php/fe/article/view/160

Isbanah, Y. (2015). Pengaruh Esop, Leverage, and Ukuran Perusahaan Terhadap Kinerja Keuangan Perusahaan Di Bursa Efek Indonesia. Jurnal Riset Ekonomi Dan Manajemen, 15(1), 28. https://doi.org/10.17970/jrem.15.150103.id

Kasmir. (2008). Bank dan Lembaga Kenangan Lainnya. PT Raja Grafindo.

Kurniawan, C. (2016). Pengaruh Investasi Terhadap Perekonomian Indonesia. Media Wahana 
Ekonomika, 12(4), 1-9.

Sari, M., \& Syechalad, M. N. (2016). Pengaruh Investasi, Tenaga Kerja Dan Pengeluaran Pemerintah Terhadap Pertumbuhan Ekonomi Di Indonesia. Jurnal Ekonomi Dan Kebijakan Publik Indonesia, 3(2), 109-115.

Sartono, A. (2010). Manajemen keuangan Teori dan Aplikasi Edisi ke Empat. BPFE.

Sudarmadji, A. M., \& Sularto, L. (2007). Pengaruh Ukuran Perusahaan, Profitabilitas, Leverage, dan Tipe Kepemilikan Perusahaan Terhadap Luas Voluntary Disclosure Laporan keuangan Tahunan. Jurnal PESAT (Psikologi, Ekonomi, Sastra, Arsitek \& Sipil), 2(2), 53-61. https://doi.org/10.1049/ip-f-1.1985.0021

Torang J.E. (2012). Metode Riset Struktur dan Pelaku Organisasi. Alfabeta.

Viandita, T. O., Suhadak, \& Husaini, A. (2013). Pengaruh Debt Ratio ( Dr ), Price To Earning Ratio ( Per ), Earning Per Share ( Eps ), Dan Size Terhadap Harga Saham. Jurnal Administrasi Bisnis, 1(2), 113-121. http://administrasibisnis.studentjournal.ub.ac.id/index.php/jab/article/view/47

Weston, \& Copeland. (1995). Manajemen Keuangan. Binarupa.

Widioatmodjo, S. (2015). Pengetahuan Pasar Modal Untuk Konteks Indonesia. PT Elex Media Komputindo.

Wufron. (2017). Pengaruh Ukuran Perusahaan Terhadap Kinerja Keuangan Serta Implikasinya Terhadap Nilai Perusahaan Pada Perusahaan Manufaktur yang Terdaftar di Bursa Efek Indonesia. Jurnal Wacana Ekonomi, 16(3), 022-033. 